Multidisciplinary

SCIENTIFIC JOURNAL OF MARITIME RESEARCH

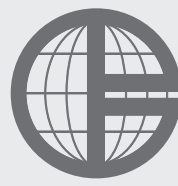

University of Rijeka

Faculty of Maritime

Studies Rijeka
Multidisciplinarni

znanstveni časopis

POMORSTVO

\title{
The role of the 4PL Model in a contemporary supply chain
}

\author{
Helga Pavlić Skender, Petra Adelajda Mirković, Ivan Prudky
}

University of Rijeka, Faculty of Economics, I. Filipovića 4, 51000 Rijeka, Croatia, e-mail: helga.pavlic.skender@efri.hr; petra.adelajda.mirković@efri.hr; e-mail: ivan.prudky@gmail.com

\section{ARTICLE INFO}

Review article

Received 29 September 2017

Accepted 4 December 2017

Key words:

Logistics operators

Fourth-party logistics operators - 4PL

Outsourcing

Supply chain management

\section{Introduction}

In the globalized world, the variety of modern distribution systems is remarkably large. The reason for it is mostly the complex customer's demand, new technological achievements and new organizational possibilities. Changes in the distribution system lead to new challenges for both companies and logistics service providers. Modern business systems often have a high degree of individualization to the requirements of end users. A competitive advantage over other companies can be achieved through collaboration with new, more advanced forms of logistics service providers. One of them is a fourth-party logistics provider (hereinafter: 4PL). The companies outsource individual operational tasks to reduce costs and increase profits (offered by third-party logistic providers, 3PL) but often overlook the need to improve the performance of products and services. Due to innovative solutions in creating an entire supply chain, 4PL operators are slowly taking the prominent position in the global logistics market. Theoretically, the 4PL operator integrates the sup- ply chain by gathering and managing resources, capabilities, and technology of its own organization with those of complementary service providers to deliver an extensive supply chain solution (Anderson, 2011).

The purpose of this paper is to analyze the advantages of the outsoursing logistics services by focusing on the 4PLs, its development, role and functions in modern business. The paper presents a conceptual framework that is based on the research of 4PL within the exsisting theorethical and empirical literature. This paper provides a knowledge-based conceptual framework for better understanding the benefits of incorporating 4PLs into modern business.

The remainder of the paper is structured as follows. The theoretical background of the logistics service providers and 4PLs related literature follows the introduction. Section 3 presents the analysis of the role of outsourcing. In section 4, the evolution of 4PLs and its function in modern business is explained. Finally, section 5 concludes and gives suggestion for the potential further development of the 4PLs analysis. 


\section{Theoretical background}

The research of 4PL dates back in late 90s when Gattorna first introduced the 4PL concept as a resources, capabilities and technology integration in order to design, build and run comperhensive supply chain solution (Subramanian et al., 2016). However, the study on 4PLs came into spotlight in the last ten years. The term 4PL was introduced by Andersen Consulting (later Accenture) as a supply chain integrator who assembles and manages the resources, capabilities, and technology of its organization with those of complementary service providers to deliver a comprehensive supply chain solution". Tomić and Poletan Jugović (2015) discuss the concept of 3PL and 4PL operator. As per Win (2008, p. 675), 4PL appears as the solution that enables companies around the world and from a distinct industry to have a unique point of liability across both supply and demand chains. Yao (2010) stated that the rewarding operation of 4PL integrates means of a supply chain reasonably, efficiently and flexibly. Papadopoulou et al. (2013) argue about a constant evolution of 4PLs within a supply chain and emphasize its innovative nature. They acknowledge that the concept of 4PL was developed and enriched through the years where diverse authors gave their own view on 4PL term and its services which are summerized in the following Table 1. Most of the authors agree that the 4PLs services are the synthesis of management, information technology and business integration.
Later research by Pavlić Skender and Grčić Fabić (2013, p. 102) describe 4PL as a separate entity who acts as a joint venture or a long-term contact between the primar client and one or more partners. They state that 4PL serves as an interface between clients and multiple logistics providers. Hlača discusses of them as global logistics operators (2016, p. 212). Additionaly, the research on 4PLs still receives many attentions as its transformation and adjustment to the logistics market demand is highly challenging.

\section{Logistics service outsourcing}

The significant use and reliance on the services of various experts, which carry out a series of logistics tasks, is the feature of the modern business systems. Diversifiction of the distribution systems was accompanied by an increase in the number of experts and consequently in the complexity of the distribution system (Jensen, 2010, str. 195). One of the possibilities of expanding a logistics organization outside of a company's boundaries is the use of 3PLs or 4PLSs, i.e. contract logistics services (Shahraki and Yazdanpour, 2013, p. 2).

Companies which use logistics services have realized that their success does not depend solely on them own, but on a network of partners capable of supplying them with new skills and technologies (Cezanne and Saglietto, 2015, p. 31). According to State of Logistics (2016), most common services when outsourcing are transport

Table 1 Literature Review on 4PLs Services

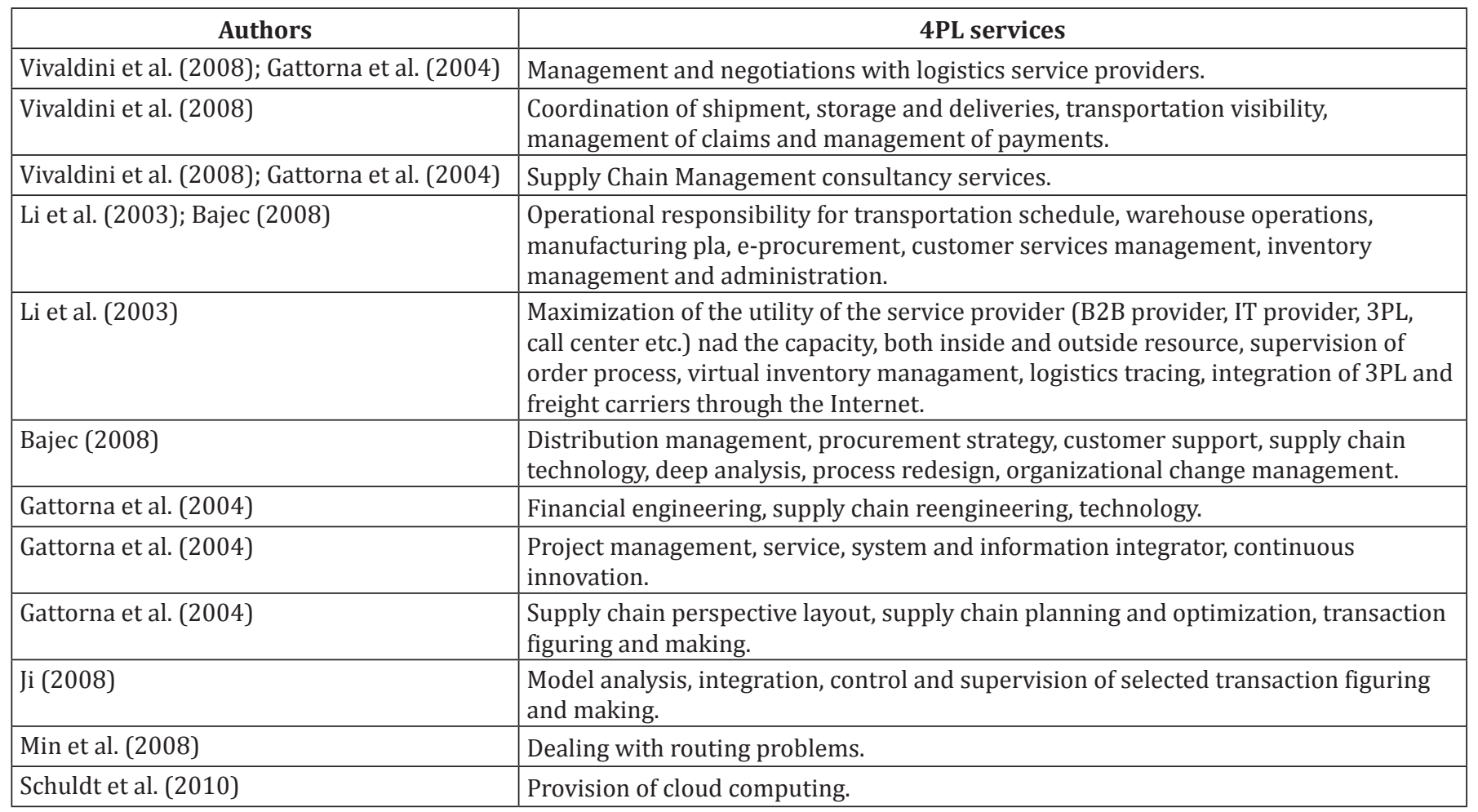

Source: Papadopoulou, 2013, p. 63 


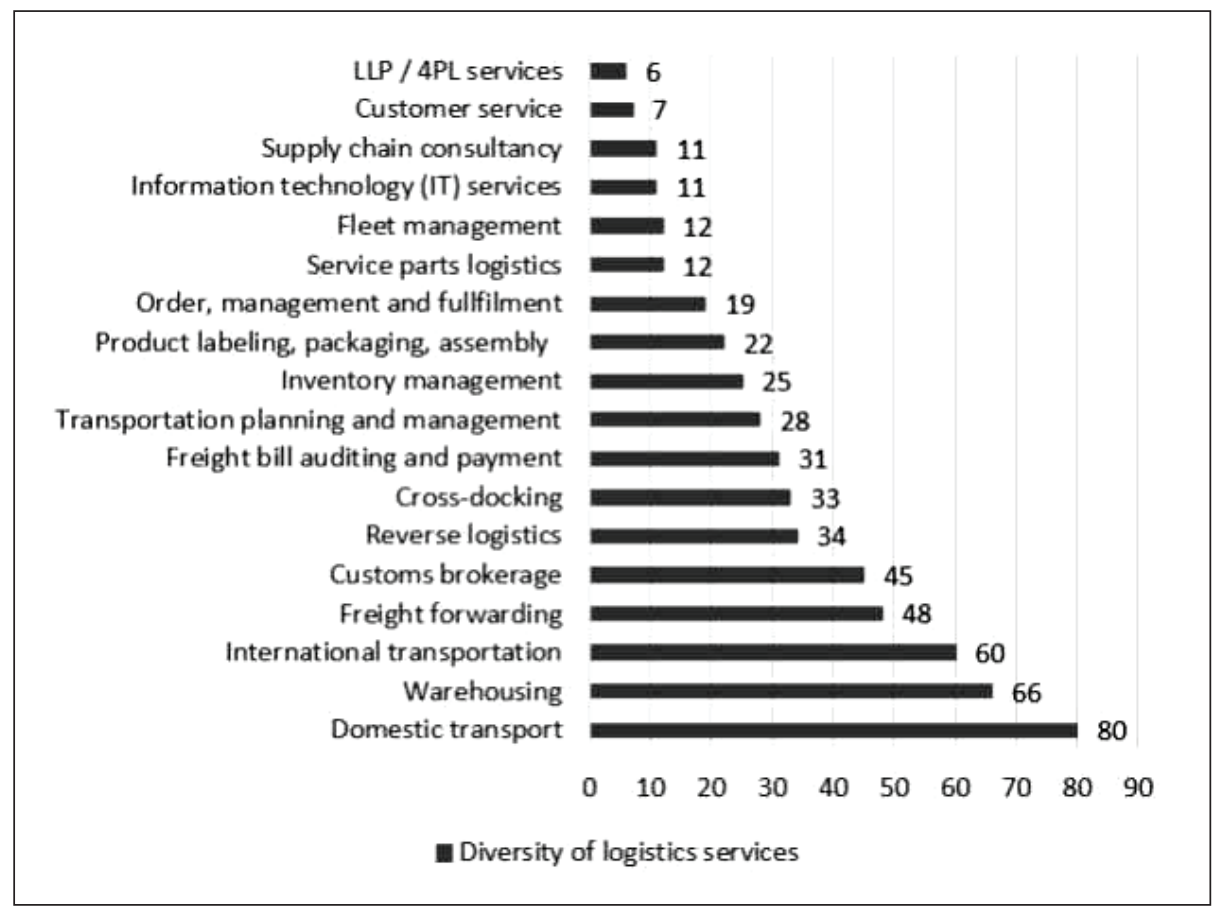

Figure 1 Outsourcing of Logistics Services by Shippers (\%)

Source: The State of Logistics, 2016, p. 13

and warehousing (Figure 1). Although the market has changed, the demand for the classic forwarding services still makes the most important share when outsourcing. Domestic and interntional transport, warehousing and freight forwarding take the leading position whilst supply chain consultancy and 4PL services take the last position.

Hence, the assumption is that in many cases companies do not entrust the consultant and managing tasks to logistics operators. The advantages of outsourcing 4PLS are still not recognized enough on the logistics market. Considering the fact that the use of 4PL is relatively new for many companies, there will always be both a natural interest in understanding, and a need to validate the use of a 4PL provider within each client's organization (Win, 2008, p. 679).

In contrast to, Papadopoulou (2013, p. 53-54) states that logistic operators should envolve into the "one-stopshop" supply chain providers. Therefor, they should expand the portfolio of the services they offer by constantly relying on advanced technology, focusing on customer needs, improving customer relationships and gradually become 4PL operators. According to the Global Logistics Report 2016 (Garner, 2017, p. 14), the need for "one-stopshop" service providers is present. Figure 2 presents the results of the survey related to the importance of a provider to be "full-service" (one stop shop). Notably, over $60 \%$ of the examinees have claimed that the provider should be one-stop- shop for all logistics needs.

Soinio, Tanskanen and Finne (2012, p. 32-33) argue how the trend of outsourcing logistics services is facilitat-

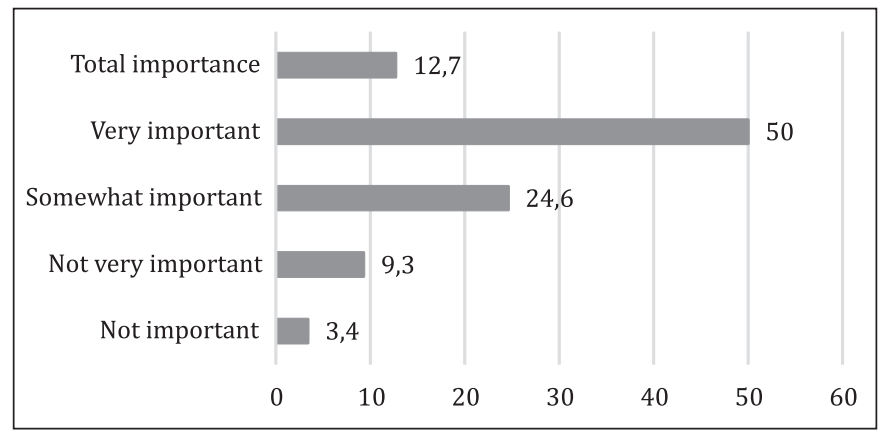

Figure 2 The Importance of a Provider to be "Full-service" - a One-stopshop for all Logistics Needs (\%)

Source: Garner, 2017, p. 14

ed by a greater integration in the supply chain processes. Those processes require multiple services as logistical information, operational knowledge and partnerships as a contribution to direct participation in the supply chain integration. Furthermore, changes in business environment, increased competition, pressure on cost reduction, and the resulting need for the restructuring of supply chains are often indicated as motives for logistics alliances (Selviaridis and Spring, 2007, p. 129).

In general, logistic operator increases its role in developing and expanding its partner relationships with the customer, thus achieving a better understanding of the performance of operational processes and the services it provides (Soinio, Tanskanen and Finne, 2012, p. 33). 


\section{Evolution and main functions of 4PLs}

The 4PL concept presents a tendency towards the new generation of outsourcing the supply chain management. Although this phenomenon has been the subject of discussion in academic circles for quite some time, unfortunately it remains just a concept. However, the latest research has confirmed its significant potential, which can lead to an enhanced competitive advantage in the contemporary business. This is a good reason for companies to rethink their logistics outsourcing strategy and transform their supply chains. Since the development of logistics service providers has greatly influenced the commercial world, it is essential that entrepreneurs, consultants, logistics experts, managers and academics understand the dynamics, opportunities and challenges of 4PLs (Cherneva and Voigir, 2015, p. 234). Nevertheless, 4PLs often have better capabilities for managing multiple resources and can help companies to deal with the complexity of high demand through optimization of the supply network (Govindan, Khodaverdi and Vafadarnjikjoo, 2016, p. 694).
Analogously, 4PL integrates all companies involved in the supply chain. Some of the task they perform are: planning, managing and controlling all logistical tasks (e.g. information, materials and capital flow) by one service provider with long-term strategic goals. These companies are in general 3PL operators who either add these features to their services or form alliances to provide services. In developing a logistics partnership, 4PLs bring these relationships to an enhanced level with higher integration and involvement of various partners (Sahay, 2006, str. 488). In addition, Figure 3 presents the differentiation of services offered by modern logistics operators, types and pricing models of their services and key logistics providers attributes.

The 4PL service provider is neutral and manages the logistics process, no matter which carriers, shippers or warehouses use it. As a result, 4PLs have become logical alternatives to outsourcing business processes by providing integration across multiple companies. 4PL users can focus on core competencies to better manage and exploit the assets and resources the company owns. 4PL is treated

\begin{tabular}{|c|c|c|c|}
\hline $\begin{array}{l}\text { Relationship } \\
\text { and pricing } \\
\text { models }\end{array}$ & Service offerings & $\begin{array}{c}\text { Logistics } \\
\text { Outsourcing }\end{array}$ & Key Attributes \\
\hline $\begin{array}{l}\text { Partnership } \\
\text { Value based }\end{array}$ & $\begin{array}{l}\text { Advanced } \\
\text { Services }\end{array}$ & $\begin{array}{c}\text { Fourth-Party } \\
\text { Logistics } \\
\text { Provider (4PL) }\end{array}$ & $\begin{array}{c}\text { Strategic relationship } \\
\text { Broad supply chain expertise } \\
\text { Knowledge and information } \\
\text { based } \\
\text { Shared risk and reward } \\
\text { Advanced technology capability } \\
\text { Adaptive, flexibile, collaborative }\end{array}$ \\
\hline $\begin{array}{l}\text { Contractual } \\
\text { Risk sharing }\end{array}$ & Load Logistics & $\begin{array}{l}\text { Lead Logistics } \\
\text { Provider (LLP) }\end{array}$ & $\begin{array}{l}\text { Project management/contract } \\
\text { management } \\
\text { Single point of contact } \\
\text { 3PL technology integration }\end{array}$ \\
\hline $\begin{array}{c}\text { Contractual } \\
\text { Fixed \& variable }\end{array}$ & Value Added & $\begin{array}{l}\text { Third-Party } \\
\text { Logistics } \\
\text { Provider (3PL) }\end{array}$ & $\begin{array}{l}\text { Enhanced capabilities } \\
\text { Broader service offerings }\end{array}$ \\
\hline $\begin{array}{l}\text { Commodity } \\
\text { Transaction }\end{array}$ & Basic Services & $\begin{array}{l}\text { Logistics } \\
\text { service provider } \\
\text { (LSP) }\end{array}$ & $\begin{array}{l}\text { Focused cost reduction } \\
\text { Niche services }\end{array}$ \\
\hline
\end{tabular}

Figure 3 Key Attributes of Logistics Outsourcing Providers 
as a strategic partner rather than as a supply chain tactical integrator who synthesizes and manages the resources, capabilities and technologies of its own organization with complementary service providers to provide a comprehensive supply chain solution (Mukhopadhyay and Setaputra, 2006, p. 718).

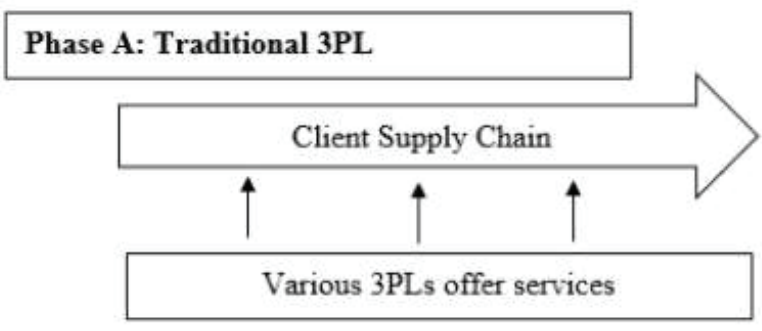

Phase B: Establishment of 4PL coordination of 3PL

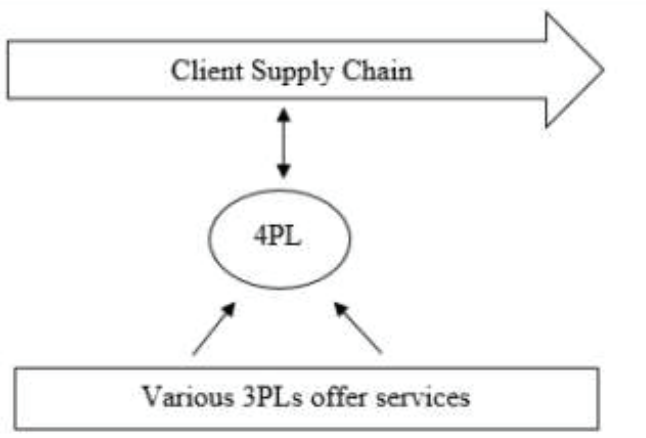

Phase C: Development and supply chain scope 4PL

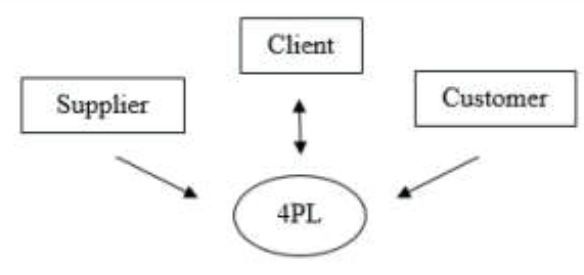

Various 3PLs offer services

Phase D: Development of supply chain

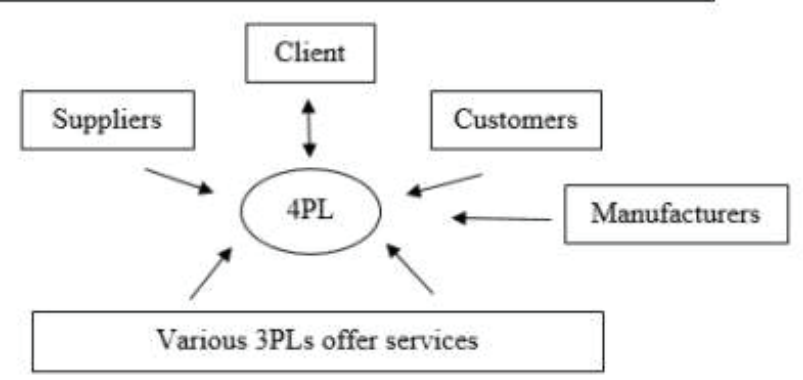

Figure 4 Change Process Implementing 4PL wih UPS Worldwide Logistics

Source: Harrison and van Hoek, 2008, p. 255
Clearly, 4PL relationships evolve from a 3PL relationship, hence 4PL have a broader role within the supply chain. 4PL have a much wider responsibility and accountability in helping the client to reach its strategic goals. In order to understand the evolution of 4PL, Figure 4 shows the phases of development and transformation of traditional 3PL into 4PL on the case of logistics provider UPS Logistics. 4PL organization acts as a unique interface between the client and the multiple providers of logistics services. All the aspects of the client's supply chain are managed by 4PL organization (Reese, 2014).

It is optimum for companies to incomporate a single partner who will assess, design, build, run and measure integrated comprehensive supply chain solutions. The key difference between $4 \mathrm{PL}$ and other logistics providers is a particular competence to deliver a value to a client across the entire supply chain. Incorporating a 4PL approach enables to deliver distinct perspective, skills and technology to the existing in-house operations.

\section{Conclusion}

The rapid change in logistic market and growing complexity of a customer's demand, new technological achievements and new organizational possibilities require collaboration with new, more advanced forms of logistics service providers. One of them is a fourth-party logistics provider (4PL). Due to innovative solutions in creating an entire supply chain, 4PL operators are slowly taking the prominent position in the global logistics market. Although the concept of fourth-party logistics provider is present in academic researches for a relatively long time, the advantages of outsourcing 4PLs are still not recognized enough on the logistics market. The paper aims to point out the advantages of the outsoursing 4PLs. This paper provides a knowledge-based conceptual framework for better understanding the benefits of incorporating 4PLs into modern business. Incorporating a 4PL approach enables to deliver distinct perspective, skills and technology to the existing in-house operations thus future researches may be broaden by implementing both qualitative and quantitative approach to evaluate the impact of fourth-party logistics provider on a business performance distinguishing among industries.

\section{Acknowledgement}

This work has been fully supported by the University of Rijeka under the project ZP UNIRI 2/17.

\section{References}

[1] Anderson, B.: 3PL vs. 4PL and why everyone's getting all confused about it, Global Logistics MEDIA, 2011.

[2] Cezanne, C., Saglietto, L.: Redefining the boundaries of the firm: the role of 4PLs, The International Journal of Logistics Management, Vol. 26, No. 1, pp. 30-41, 2015. 
[3] Cherneva, D., Voigir, K.-I.: Outsourcing to 4PLs - Opportunities, Challenges, Future Outlook, Innovations and Strategies for Logistics and Supply Chains, Vol. 20, No. 1, pp. 231-255, 2015.

[4] Garner, H.: 2016 Global Logistics Report, Eyefortransport, http://www.eft.com/content/2016-global-logistics-report (12. 05. 2017.)

[5] Govindan, K., Khodaverdi, R., Vafadarnikjoo, A.: 'A grey DEMATEL approach to develop third-party logistics provider selection Criteria', Industrial Management \& Data Systems, Vol. 116, No. 4, pp. 690-722, 2016.

[6] Harrison, A., van Hoek, R.: Logistics Management and Strategy, Pearson Education Limited, Harlow, 2008.

[7] Hlača, B.: Lučka logistika, Pomorski fakultet Sveučilišta u Rijeci, Rijeka, 2016.

[8] Jensen, L.-M.: Opportunities and constraints for intermediaries in distribution: The challenge of variety, The IMP Journal, Vol. 4, No. 3, pp. 194-219, 2010.

[9] Mukhopadhyay, S. K., Setaputra, R.: The role of 4PL as the reverse logistics integrator: optimal pricing and return policies, International Journal of Physical Distribution and Logistics Management, Vol. 36, No. 7, pp. 716-729, 2006.

[10] Papadopoulou, E.-M.: Logistics Service Providers: Collaboration with IFFs, 3PL, or 4PL Providers?, Outsourcina Management for Supply Chain Operations and Logistics Services, ed. D Folinas, ATEI-Thessalonaiki, Greece, 2013.

[11] Pavlić Skender, H., Grčić Fabić, M.: Logistički špediter u fokusu prometnog i gospodarskog sustava, Pomorski zbornik, Vol. 47 No. 48, pp. 95-107, 2013.

[12] Reese, A.: The 4PL: Partner for the Global Supply Chain, Supply \& Demand Chain Executive, 2014.
[13] Sahay, B. S.: 3PL, 4PL and reverse logistics: part 1, International Journal of Physical Distribution and Logistics Management, Vol. 36, No. 7, 2006.

[14] Selviaridis, K., Spring, M.: Third party logistics: a literature review and research Agenda, The International Journal of Logistics Management, Vol. 18, No. 1, pp. 125-150, 2007.

[15] Shahraki, A., Yazdanpour, M.: LSP, 3PL, LLP, 4PL - Which One Come In Useful For Outsourcing Cycle!, Islamic Azdad University - Zahden Unit, 2013.

[16] Soinio, J., Tanskanen, K., Finne, M.: How logistics-service providers can develop value-added services for SMEs: a dyadic perspective, The International Journal of Logistics Management, Vol. 23, No. 1, pp. 31-49, 2012.

[17] Subramanian, N., Gunasekaran, A., Papadopulos, T., Nie, P.: 4 th party logistics service providers and industrial cluster competitiveness, Industrial Management \& Dana Systems, Vol. 116, No. 7, pp. 1303-1330, 2016.

[18] The State of Logistics Outsourcing, 2016, 2016 ThirdParty Logistics Study, http://manufacturing.sco-summit. com/2017/data/report/pdf/2016_3PL_Study.pdf, (25. 05. 2017).

[19] Tomić, M., Poletan Jugović, T.: Principi konkurentskog poslovanja na tržištu logističko-špediterskih usluga, Zbornik Sveučilišta u Dubrovniku, Dubrovnik, pp. 209-222, 2015.

[20] Win, A.: The value a 4PL provider can contribute to an organisation, International Journal of Physical Distribution \& Logistics Management, Vol. 38 No. 9, pp. 674-684, 2008.

[21] Yao, J.: Decision optimization analysis on supply chain resource integration in fourth party logistics, Journal of Manufacturing System, Vol. 29, No. 4, pp. 121-129, 2010. 